\title{
Effectiveness of COVID-19 Vaccines among Incarcerated People in California State Prisons: A Retrospective Cohort Study
}

Elizabeth T. Chin, BS ${ }^{1}$, David Leidner, $\mathrm{PhD}^{2}$, Yifan Zhang, $\mathrm{PhD}^{3}$, Elizabeth Long, $\mathrm{MS}^{3}$, Lea Prince, $\mathrm{PhD}^{3}$, Stephanie J. Schrag, DPhil ${ }^{4}$, Jennifer R. Verani, MD, MPH ${ }^{4}$, Ryan E. Wiegand, $\mathrm{MS}^{4}$, Fernando Alarid-Escudero, $\mathrm{PhD}^{5}$, Jeremy D. Goldhaber-Fiebert, $\mathrm{PhD}^{3}$, David M. Studdert, LLB ScD ${ }^{3,6}$, Jason R. Andrews, MD MS ${ }^{7}$, Joshua A. Salomon, $\mathrm{PhD}^{3}$

\section{Author affiliations:}

(1) Department of Biomedical Data Science, Stanford University, Stanford, CA, USA.

(2) California Department of Corrections and Rehabilitation, Sacramento, CA, USA

(3) Stanford Health Policy and Department of Medicine, Stanford University School of Medicine, Stanford, CA, USA

(4) Centers for Disease Control and Prevention, Atlanta, GA, USA.

(5) Division of Public Administration, Center for Research and Teaching in Economics (CIDE), Aguascalientes, Aguascalientes, Mexico

(6) Stanford Law School, Stanford, CA, USA

(7) Department of Medicine, Stanford University School of Medicine, Stanford, CA, USA

Abstract: 298; Text: 3,082

Disclaimer: The findings and conclusions in this report are those of the authors and do not necessarily represent the official position of the Centers for Disease Control and Prevention. 


\section{Background}

Prisons and jails are high-risk settings for COVID-19 transmission, morbidity, and mortality.

COVID-19 vaccines may substantially reduce these risks, but evidence is needed of their effectiveness for incarcerated people, who are confined in large, risky congregate settings.

\section{Methods}

We conducted a retrospective cohort study to estimate effectiveness of mRNA vaccines, BNT162b2 (Pfizer-

BioNTech) and mRNA-1273 (Moderna), against confirmed SARS-CoV-2 infections among incarcerated people in California prisons from December 22, 2020 through March 1, 2021. The California Department of Corrections and Rehabilitation provided daily data for all prison residents including demographic, clinical, and carceral characteristics, as well as COVID-19 testing, vaccination status, and outcomes. We estimated vaccine effectiveness using multivariable Cox models with time-varying covariates that adjusted for resident characteristics and infection rates across prisons.

\section{Findings}

Among 60,707 residents in the cohort, 49\% received at least one BNT162b2 or mRNA-1273 dose during the study period. Estimated vaccine effectiveness was 74\% (95\% confidence interval [CI], 64-82\%) from day 14 after first dose until receipt of second dose and 97\% (95\% CI, 88-99\%) from day 14 after second dose. Effectiveness was similar among the subset of residents who were medically vulnerable (74\% [95\% CI, 62-82\%] and 92\% [95\% CI, 74-98\%] from 14 days after first and second doses, respectively), as well as among the subset of residents who received the mRNA-1273 vaccine (71\% [95\% CI, 58-80\%] and 96\% [95\% CI, 67-99\%]).

\section{Conclusions}

Consistent with results from randomized trials and observational studies in other populations, mRNA vaccines were highly effective in preventing SARS-CoV-2 infections among incarcerated people. Prioritizing incarcerated people 
medRxiv preprint doi: https://doi.org/10.1101/2021.08.16.21262149; this version posted August 18, 2021. The copyright holder for this preprint (which was not certified by peer review) is the author/funder, who has granted medRxiv a license to display the preprint in perpetuity.

All rights reserved. No reuse allowed without permission.

for vaccination, redoubling efforts to boost vaccination and continuing other ongoing mitigation practices are essential in preventing COVID-19 in this disproportionately affected population.

\section{Funding}

Horowitz Family Foundation, National Institute on Drug Abuse, Centers for Disease Control and Prevention, National Science Foundation, Open Society Foundation, Advanced Micro Devices. 
medRxiv preprint doi: https://doi.org/10.1101/2021.08.16.21262149; this version posted August 18, 2021. The copyright holder for this preprint (which was not certified by peer review) is the author/funder, who has granted medRxiv a license to display the preprint in perpetuity.

All rights reserved. No reuse allowed without permission.

\section{Introduction}

The BNT162b2 (Pfizer-BioNTech) and mRNA-1273 (Moderna) vaccines appear highly effective in preventing severe acute respiratory syndrome coronavirus 2 (SARS-CoV-2) infection and coronavirus disease 2019 (COVID19) illness. Augmenting efficacy evidence from clinical trials, ${ }^{1,2}$ observational studies among healthcare workers, ${ }^{3,4}$ adults aged 65 years or older, ${ }^{5}$ and the general community ${ }^{6,7}$ have reported levels of protection from full vaccination ranging from $89 \%$ to $95 \%$. However, except for two relatively small studies of partial vaccination in skilled nursing facilities $^{8,9}$, no published studies to date have examined the effectiveness of COVID-19 vaccines in congregate settings, where risks of transmission are very high.

Prisons and jails are especially risky congregate settings. Living quarters are often densely populated and poorly ventilated, physical distancing is typically infeasible, and pre-existing medical conditions associated with severe COVID-19 illness are prevalent among incarcerated people. ${ }^{10,11}$ Recognizing these risks and the considerable potential for vaccines to reduce them, approximately half of states in the USA have prioritized incarcerated people for COVID-19 vaccines. In contrast, 15 states have not included incarcerated people in vaccine distribution plans or have assigned them to lowest priority tiers. ${ }^{12,13}$

The California Department of Corrections and Rehabilitation (CDCR), which operates the second largest state prison system in the USA, launched a COVID-19 vaccination program on December 22, 2020, and rapidly scaled up the program across its 35 prisons. ${ }^{14} \mathrm{CDCR}$ has conducted extensive testing and collected detailed data relevant to COVID-19 risks, interventions, and outcomes. We analyzed these data to estimate effectiveness of mRNA vaccines against confirmed SARS-CoV-2 infection among nearly 61,000 incarcerated people in California.

\section{Methods}

\section{Study design and population}

We conducted a retrospective cohort study spanning the 70-day period from December 22, 2020, through March 1, 2021, during which residents were offered either BNT162b2 or mRNA-1273 vaccines. Prioritization criteria CDCR used to direct first-dose offers changed over time as supply expanded and state and federal guidance evolved.

Criteria included residency in a specialized medical or psychiatric care setting, age and medical comorbidities, no 
confirmed SARS-CoV-2 infection (or none in the previous 90 days), and participation in penal labor. CDCR prioritized timely second-dose offers to adhere to recommended dosing schedules.

Residents were eligible for inclusion in the study cohort if they were incarcerated in a CDCR prison on the study start date and had no prior confirmed SARS-CoV-2 infection. Cohort members contributed observation time beginning on the study start date and ending on the day of the earliest of the following events: release from CDCR custody, sample collection for a positive SARS-CoV-2 diagnostic test, or study end date.

\section{Data and key measures}

CDCR collects and stores daily data on each resident. Data provided for this study included demographic characteristics (sex, age, racial or ethnic group), documented history of 25 comorbid conditions (e.g., hypertension, chronic kidney disease, asthma), and a composite COVID-19 risk score. CDCR designed the COVID-19 risk score to grade risks of severe illness from SARS-CoV-2 infections based on individual demographic and clinical information (Table S1), and the agency has used this score to guide COVID-19 mitigation policies, including prioritization of testing and vaccination. We also obtained person-day level variables indicating each resident's prison, facility, building, housing unit, floor, and room of residence; room type (cell or dormitory); security level; and participation in penal labor.

Detailed SARS-CoV-2 testing information came from a multilayered resident testing program that included risk-based routine testing, surveillance testing, and testing in response to detected outbreaks (Table S2). Information provided on accepted vaccine doses allowed us to classify cohort members' daily vaccination status into six categories: unvaccinated, from 0 to 6 days after receiving a first dose, from 7 to 13 days after a first dose, from 14 days after a first dose until receipt of a second dose, from 0 to 13 days after a second dose, and from 14 days after a second dose.

To obtain a measure of risk of infection from correctional staff, we constructed a prison-day level variable comprising the rolling 7-day COVID-19 case rate among staff at each prison. Infections among correctional staff were identified through a program of regular SARS-CoV-2 testing, mandated and administered by CDCR (Table S2). 
medRxiv preprint doi: https://doi.org/10.1101/2021.08.16.21262149; this version posted August 18, 2021. The copyright holder for this preprint (which was not certified by peer review) is the author/funder, who has granted medRxiv a license to display the preprint in perpetuity.

All rights reserved. No reuse allowed without permission.

\section{Statistical analysis}

To obtain estimates of vaccine effectiveness, we fit multivariable models using the Andersen-Gill extension of the Cox proportional hazards mode ${ }^{15}$ to account for time-varying covariates using person-day level data. The primary outcome of interest was SARS-CoV-2 infection, confirmed by positive PCR or antigen test. We specified exposure status according to the six vaccination categories described above. Effectiveness estimates are expressed as 1 minus the hazard ratio.

Analyses adjusted for residents' racial or ethnic group, COVID-19 risk score, security level, room type, participation in penal labor, staff case rate, and prison (fixed effects). We did not adjust for sex because men and women are generally housed in separate prisons, making this variable highly collinear with prison. To account for non-independence between cohort members, we clustered standard errors by housing unit. Housing units are discrete cohorts within prisons, consisting of residents who co-participate in activities (e.g., recreation, laundry, dining).

All analyses were performed using R software, version 3.5.2 (R Foundation for Statistical Computing). Additional details regarding model and variable specifications are provided in the Supplementary Appendix.

\section{Secondary analyses}

We conducted four sets of secondary analyses. First, we estimated effectiveness in two subgroups of interest. Specifically, recognizing that our primary analysis mixes effects of two different vaccines, we ran one subgroup analysis focusing on mRNA-1273 vaccinations only (which accounted for 78\% of all first doses and $72 \%$ of all doses administered in the study period). We also estimated effectiveness among medically vulnerable residents by restricting the analytic cohort to residents with COVID-19 risk scores of 2 or higher, indicating moderate or high risk. Residents with COVID-19 risk scores of 2 or higher were either aged 65 years and older or younger than 65 years with comorbid conditions associated with severe COVID-19 disease (Table S1).

Second, we estimated effectiveness in a broader population that included residents with prior infections and those who entered prison during the study period. Third, we examined the sensitivity of our effectiveness estimates to alternative model specifications, including censoring observation time at the collection date of cohort members' last test (to exclude time periods in which infection status was unknown), and computing cluster-robust variance estimators with clusters defined at various levels (prison, facility, building, housing unit, floor, room, and person). 
medRxiv preprint doi: https://doi.org/10.1101/2021.08.16.21262149; this version posted August 18, 2021. The copyright holder for this preprint (which was not certified by peer review) is the author/funder, who has granted medRxiv a license to display the preprint in perpetuity.

All rights reserved. No reuse allowed without permission.

Finally, to assess the sensitivity of estimates to choice of study period, we re-estimated effectiveness using a series of alternative study end dates between February 15 and July 1, 2021.

\section{$\underline{\text { Study oversight }}$}

The study was approved by the institutional review board at Stanford University (protocol \#55835). It was reviewed by CDC and conducted according to applicable federal law and CDC policy. ${ }^{*}$ Results are reported in accordance with Strengthening the Reporting of Observational Studies in Epidemiology (STROBE) guidelines (checklist in Supplementary Appendix). ${ }^{16}$

\section{Results}

Sample characteristics and vaccination uptake

60,707 residents met the cohort inclusion criteria (Figure S1) and were followed for an average of 57.6 days (median, 70 days). By February 1, 2021, 20\% of them received at least one mRNA dose and 3\% received two doses; by March 1, 49\% received at least one dose and 22\% received two doses (Figure 1). The mean interval between doses was 20.8 days (standard deviation [SD]: 2.7) for those who received two BNT162b2 doses and 28.0 days (SD: 3.5) days for those who received two mRNA-1273 doses.

Most cohort members were male (96\%), younger than 60 years (88\%), and either Hispanic or Latino (43\%) or non-Hispanic Black or African American (33\%) (Table 1). Most had risk factors for severe outcomes from COVID-19 infection: 84\% had at least one medical condition defined by CDC as a marker of severe COVID-19related illness, ${ }^{17}$ and $31 \%$ had moderate or high COVID-19 risk according to CDCR's scoring algorithm. Cohort members who had received one or more vaccine doses by the end of the study period tended to be older than those who had not, and were more likely to have medical conditions and higher COVID-19 risk scores and be nonHispanic White or Hispanic or Latino (Table 1).

\footnotetext{
${ }^{*}$ See e.g., 45 C.F.R. part 46, 21 C.F.R. part 56; 42 U.S.C. §241(d); 5 U.S.C. §552a; 44 U.S.C. §3501 et seq.
} 
medRxiv preprint doi: https://doi.org/10.1101/2021.08.16.21262149; this version posted August 18, 2021. The copyright holder for this preprint (which was not certified by peer review) is the author/funder, who has granted medRxiv a license to display the preprint in perpetuity.

All rights reserved. No reuse allowed without permission.

\section{Testing rates by vaccination category}

Cohort members had a median of 6 COVID-19 tests during the study period (interquartile range: 2-10). Testing rates were lower in the unvaccinated group (Figure S2). In January 2021, for example, there were 933 tests per 10,000 person-days among the unvaccinated group, compared with 1,167 among the partially vaccinated group $(\geq 14$ days after first dose until receipt of second dose) and 2,018 among the fully vaccinated group ( $\geq 14$ days after second dose). The rate of testing decreased from 957 tests per 10,000 person-days in January to 886 in February.

\section{Confirmed infections and other COVID-19 outcomes}

A total of 13,216 confirmed infections (37.8 per 10,000 person-days), 393 hospitalizations (1.1 per 10,000 persondays), and 48 deaths (0.1 per 10,000 person-days) were documented among cohort members. Most of these outcomes occurred among unvaccinated people (Table 2). Incidence of confirmed infection was 0.6 per 10,000 person-days among the fully vaccinated, 3.5 among the partially vaccinated, and 46.8 among the unvaccinated. Incidence of infection decreased during the study period, from 40.2 per 10,000 person-days in January 2021 to 11.8 in February (Figure 1). Additional details on testing and confirmed infections, including time series by specific prison, are shown in Figures S2, S3, and S4 in the Supplementary Appendix.

\section{Vaccine effectiveness}

There was no significant difference in the adjusted hazard ratio for confirmed SARS-CoV-2 infection during days 0 to 6 days after receiving a first dose relative to unvaccinated status (Table 2). From 7 to 13 days after a first dose, estimated vaccine effectiveness was 44\% (95\% CI, 20-61\%), and from 14 days after a first dose until receipt of a second dose, effectiveness was 74\% (95\% CI, 64-82\%). Effectiveness estimates were 85\% (95\% CI, 66-94\%) from 0 to 13 days after a second dose and $97 \%$ (95\% CI, 88-99\%) from 14 days after a second dose.

\section{$\underline{\text { Secondary analyses }}$}

Subgroup analyses produced similar estimates of effectiveness to the full cohort analysis (Table S3A). Among those receiving the mRNA-1273 vaccine, estimated effectiveness was 71\% (95\% CI, 58-80\%) from 14 days after first dose until receipt of second dose and 96\% (95\% CI, 67-99\%) from 14 days after second dose. Among cohort members at moderate or high risk for severe COVID-19 illness, effectiveness estimates were 74\% (95\% CI, 62- 
medRxiv preprint doi: https://doi.org/10.1101/2021.08.16.21262149; this version posted August 18, 2021. The copyright holder for this preprint (which was not certified by peer review) is the author/funder, who has granted medRxiv a license to display the preprint in perpetuity.

All rights reserved. No reuse allowed without permission.

$82 \%$ ) from 14 days after first dose until receipt of second dose and 92\% (95\% CI, 74-98\%) from 14 days after second dose.

Estimates in an expanded cohort that included new entrants and residents with prior infections did not differ appreciably from the main cohort analysis (Table S3B). Results were also insensitive to model specification choices, including censoring of observation time at the date of cohort members' last test and clustering standard errors at different residential levels (Table S3C and S3D).

In secondary analyses that modified the study end date, effectiveness estimates for fully vaccinated residents (i.e., from 14 days after second dose) decreased from 98\% (95\% CI, 82-100\%) to 82\% (95\% CI, 69-89\%) over a series of end dates between February 15 and July 1, 2021 (Table S3E). Study months spanning March to July were characterized by significantly lower outbreak risks across all facilities ( 0.4 confirmed infections per 10,000 person-days); lower testing (474 tests per 10,000 person-days); and high overall vaccination coverage rates (72\% and $75 \%$ of cohort members who were still in custody had received at least one dose or had tested positive by April 1 and July 1 , respectively).

\section{Discussion}

This study found that BNT162b2 and mRNA-1273 vaccines were highly effective against confirmed SARS-CoV-2 infection among members of a high-risk and racially diverse population of incarcerated people. Beginning 14 days after a second mRNA vaccine dose, estimated effectiveness in this population was $97 \%$. The vaccines were also highly effective among prison residents at higher risk for severe COVID-19 illness.

Our estimates of effectiveness among fully-vaccinated people in California prisons was higher than estimates reported by Cavanaugh et $\mathrm{al}^{8}$ from a skilled nursing facility in the USA (66\% among residents and 76\% among staff from 14 days after a second BNT162b2 dose), though similar to those reported for healthcare and other frontline workers by Thompson et $\mathrm{al}^{3}$ in the USA ( $91 \%$ from 14 days after second mRNA vaccine dose) and Angel et $^{4} l^{4}$ in Israel ( $86 \%$ from 7 days after second BNT162b2 dose). Population-level studies in Israel by Dagan et $\mathrm{al}^{7}$ and Haas et $\mathrm{al}^{6}$ also reported similar results (92\% and 95\%, respectively, from 7 days after second BNT162b2 dose) as our study. Estimates of effectiveness of partial vaccination are more variable. We estimated $74 \%$ effectiveness against infection from 14 days after a first mRNA vaccine dose until receipt of second dose. This result was lower than Thompson et al's ${ }^{3}$ estimate of $81 \%$ among healthcare and other frontline workers from 14 days after first 
medRxiv preprint doi: https://doi.org/10.1101/2021.08.16.21262149; this version posted August 18, 2021. The copyright holder for this preprint (which was not certified by peer review) is the author/funder, who has granted medRxiv a license to display the preprint in perpetuity. All rights reserved. No reuse allowed without permission.

mRNA vaccine dose until 14 days after second dose, but substantially higher than Dagan et al's ${ }^{7}$ estimates of $46 \%$ for days 14 through 20 after first BNT162b2 dose and 60\% for days 21 through 27.

To our knowledge, this is the first study to assess effectiveness of a COVID-19 vaccination program in a carceral setting. It has several strengths. We used detailed daily information on vaccination status and key COVID19 outcomes for each resident. These data allowed us to adjust for key potential confounders, including risk factors for severe COVID-19, housing arrangements, and participation in penal labor. An extensive testing program in this population facilitated relatively complete measurement of SARS-CoV-2 infections. In addition, the large sample size permitted estimates of effectiveness within particular subgroups of interest (e.g., medically vulnerable).

Understanding vaccine effectiveness among people at high risk for severe disease is a priority. Our estimated effectiveness for partial and full vaccination did not differ appreciably between the full cohort and subsets characterized by moderate or high risk for severe COVID-19 illness. This bolsters growing evidence that mRNA vaccines provide substantial protection in older adults, ${ }^{5,7}$ people with pre-existing conditions, ${ }^{7,18}$ and residents of skilled nursing facilities. ${ }^{8}$ Our results also extend evidence from studies of healthcare workers indicating these vaccines are effective in environments characterized by high transmission risks.

In observational cohort studies like ours, potential for bias due to confounding is an important consideration. Vaccines were not offered randomly to residents — in particular those with risk factors for severe disease were prioritized. Given the latency of biologically plausible protection, the days after vaccination can serve as an indicator of bias, with large effectiveness estimates signaling substantial residual confounding. ${ }^{19} \mathrm{We}$ included an exposure category for the first week after a first mRNA vaccine dose to assess the presence of such residual confounding, and detected a statistically insignificant $16 \%$ effectiveness for this negative control exposure. Vasileiou et al. ${ }^{18}$ reported a much higher estimate, $86 \%$ protection against COVID-19 hospitalizations during the first week after vaccination for BNT162b2, in a previous study on effectiveness in Scotland.

Residents were tested frequently (median 6 tests) during the 70-day study period, but testing was neither routine, random nor compulsory, creating potential for ascertainment bias. Several results provide some reassurance in this regard. First, vaccinated cohort members overall had 25\% higher testing rates than unvaccinated members. Thus, the most plausible bias from differential testing would be more complete case detection among the vaccinated, which would lead to underestimating vaccine effectiveness. Second, an analysis that censored follow-up on the last test collection date for a cohort member produced effectiveness estimates similar to those from the main analysis. 
Extending the study period through July 1, 2021 added four months in which testing and case rates were low, and a relatively large proportion of prison residents had been vaccinated. We found lower levels of estimated effectiveness for the fully vaccinated group over this extended period — an expected result, and a trend seen in the six-month vaccine efficacy clinical trial for the BNT162b2 vaccine. ${ }^{20}$ Accumulation of undetected infections that confer natural immunity may have contributed to dilution of estimated effectiveness, especially among residents at lower risk for severe COVID-19, who were generally tested less frequently and vaccinated later in the study period. Additional contributors may have included increasing bias in the composition of the unvaccinated group towards residents who declined vaccination, as well as cohort selection induced by heterogeneity in infection risk. ${ }^{21}$ For instance, if the vaccine offered partial (or "leaky") protection, ${ }^{22}$ high infection risk within an unvaccinated group that is initially highly susceptible could induce selection bias over time as the most susceptible people are removed from the group, which would decrease estimated effectiveness of vaccination.

The study has several other limitations. First, our estimates of effectiveness focused on confirmed infections, not other important outcomes, such as symptomatic infections or severe disease. Incidence of hospitalizations and deaths in our cohort during the study period was too low to support rigorous analysis of those outcomes, and symptom reporting is unreliable in carceral settings. ${ }^{23} \mathrm{~A}$ related point is that we were only able to estimate effectiveness in relation to the date of test sample collection, not transmission date, which allows for the possibility that some detected infections might have preceded vaccination. Second, we evaluated effectiveness against any SARS-CoV-2 infection, not specific viral variants, because CDCR conducted limited viral genome sequencing during the study period. As the B.1.617.2 (delta) variant became dominant and cases rose in the general community over the months of June and July, ${ }^{24,25}$ CDCR detected a total of 286 cases among a population of nearly 99,000 residents during this period, ${ }^{26}$ a substantially lower rate when compared to the period between mid-March 2020 to mid-February 2021, during which the number of cases were above 200 in almost every week, peaking at 5,659 weekly cases in December 2020. Low incidence after February 2021 suggests that there may be substantial protection against outbreaks in this population with high levels of vaccination and prior infections, including during a period marked by increasing prevalence of more highly transmissible variants. However, as people continue to become infected and more outbreaks occur, further follow-up is necessary to reassess the effectiveness and protection afforded by vaccines. Third, CDCR used some antigen tests, which have lower sensitivity, potentially leading to under-detection of cases. However, at least $93 \%$ of all tests were PCR, so we expect any bias related to 
medRxiv preprint doi: https://doi.org/10.1101/2021.08.16.21262149; this version posted August 18, 2021. The copyright holder for this preprint (which was not certified by peer review) is the author/funder, who has granted medRxiv a license to display the preprint in perpetuity.

All rights reserved. No reuse allowed without permission.

antigen testing to be minimal. Finally, the generalizability of our results to residents of jails and other correctional systems is unknown.

Residents of prisons and jails have borne a disproportionately large share of disease burden during the COVID-19 pandemic. Findings from this study-building on a growing evidence base indicating vaccine efficacy and effectiveness across a range of populations and settings-suggest that mRNA vaccines are extremely effective in protecting incarcerated people against infection, including residents at high risk of severe COVID-19 illness.

Continued emphasis on vaccination and other ongoing mitigation practices are essential in preventing COVID-19 in this disproportionately affected population. Incarcerated people, correctional workers, and the wider community all stand to benefit from those efforts. 
medRxiv preprint doi: https://doi.org/10.1101/2021.08.16.21262149; this version posted August 18, 2021. The copyright holder for this preprint (which was not certified by peer review) is the author/funder, who has granted medRxiv a license to display the preprint in perpetuity. All rights reserved. No reuse allowed without permission.

\section{References}

1. Polack FP, Thomas SJ, Kitchin N, et al. Safety and Efficacy of the BNT162b2 mRNA Covid-19 Vaccine. New England Journal of Medicine 2020;383(27):2603-15.

2. Baden LR, El Sahly HM, Essink B, et al. Efficacy and Safety of the mRNA-1273 SARS-CoV-2 Vaccine. New England Journal of Medicine 2021;384(5):403-16.

3. Thompson MG, Burgess JL, Naleway AL, et al. Prevention and Attenuation of Covid-19 with the BNT162b2 and mRNA-1273 Vaccines. New England Journal of Medicine 2021;

4. Angel Y, Spitzer A, Henig O, et al. Association Between Vaccination With BNT162b2 and Incidence of Symptomatic and Asymptomatic SARS-CoV-2 Infections Among Health Care Workers. JAMA 2021;

5. Tenforde MW, Olson SM, Self WH, et al. Effectiveness of Pfizer-BioNTech and Moderna Vaccines Against COVID-19 Among Hospitalized Adults Aged $\geq 65$ Years - United States, January-March 2021. MMWR Morb Mortal Wkly Rep 2021;70(18):674-9.

6. Haas EJ, Angulo FJ, McLaughlin JM, et al. Impact and effectiveness of mRNA BNT162b2 vaccine against SARS-CoV-2 infections and COVID-19 cases, hospitalisations, and deaths following a nationwide vaccination campaign in Israel: an observational study using national surveillance data. Lancet 2021;397(10287):1819-29.

7. Dagan N, Barda N, Kepten E, et al. BNT162b2 mRNA Covid-19 Vaccine in a Nationwide Mass Vaccination Setting. N Engl J Med 2021;384(15):1412-23.

8. Cavanaugh AM, Fortier S, Lewis P, et al. COVID-19 Outbreak Associated with a SARS-CoV-2 R.1 Lineage Variant in a Skilled Nursing Facility After Vaccination Program - Kentucky, March 2021. MMWR Morb Mortal Wkly Rep 2021;70(17):639-43.

9. Britton A, Jacobs Slifka KM, Edens C, et al. Effectiveness of the Pfizer-BioNTech COVID-19 Vaccine Among Residents of Two Skilled Nursing Facilities Experiencing COVID-19 Outbreaks — Connecticut, December 2020-February 2021. MMWR Morb Mortal Wkly Rep 2021;70(11):396-401.

10. Chin ET, Ryckman T, Prince L, et al. COVID-19 in the California State Prison System: an Observational Study of Decarceration, Ongoing Risks, and Risk Factors. J Gen Intern Med. 2021;1-7.

11. National Academies of Sciences, Engineering, and Medicine. 2020. Decarcerating Correctional Facilities during COVID-19: Advancing Health, Equity, and Safety. Washington, DC: The National Academies Press. https://doi.org/10.17226/25945.

12. Maner M. An Analysis of Interim COVID-19 Vaccination Plans. COVID Prison Project. June 52021 (https://covidprisonproject.com/blog/data/data-analysis/an-analysis-of-interim-covid-19-vaccination-plans/).

13. Strodel R, Dayton L, Garrison-Desany HM, et al. COVID-19 vaccine prioritization of incarcerated people relative to other vulnerable groups: An analysis of state plans. PLOS ONE 2021;16(6):e0253208.

14. Chin ET, Leidner D, Ryckman T, et al. Covid-19 Vaccine Acceptance in California State Prisons. N Engl J Med. 2021;385(4):374-376.

15. Andersen PK, Gill RD. Cox's Regression Model for Counting Processes: A Large Sample Study. The Annals of Statistics 1982;10(4):1100-20. 
medRxiv preprint doi: https://doi.org/10.1101/2021.08.16.21262149; this version posted August 18, 2021. The copyright holder for this preprint

(which was not certified by peer review) is the author/funder, who has granted medRxiv a license to display the preprint in perpetuity.

All rights reserved. No reuse allowed without permission.

16. von Elm E, Altman DG, Egger M, et al. The Strengthening the Reporting of Observational Studies in Epidemiology (STROBE) statement: guidelines for reporting observational studies. Lancet 2007;370(9596):1453-7.

17. Centers for Disease Control and Prevention. People with Certain Medical Conditions. May 13, 2021

(https://www.cdc.gov/coronavirus/2019-ncov/need-extra-precautions/people-with-medical-conditions.html).

18. Vasileiou E, Simpson CR, Shi T, et al. Interim findings from first-dose mass COVID-19 vaccination roll-out and COVID-19 hospital admissions in Scotland: a national prospective cohort study. Lancet 2021;397(10285):1646-57.

19. Hitchings MDT, Lewnard JA, Dean NE, et al. Use of recently vaccinated individuals to detect bias in testnegative case-control studies of COVID-19 vaccine effectiveness. medRxiv 2021.

20. Thomas SJ, Moreira ED, Kitchin N, et al. Six Month Safety and Efficacy of the BNT162b2 mRNA COVID19 Vaccine. medRxiv 2021.

21. Gomes MGM, Gordon SB, Lalloo DG. Clinical trials: The mathematics of falling vaccine efficacy with rising disease incidence. Vaccine 2016;34(27):3007-9.

22. Lewnard JA, Tedijanto C, Cowling BJ, Lipsitch M. Measurement of Vaccine Direct Effects Under the TestNegative Design. American Journal of Epidemiology 2018;187(12):2686-97.

23. Ryckman T, Chin ET, Prince L, et al. Outbreaks of COVID-19 variants in US prisons: a mathematical modelling analysis of vaccination and reopening policies. Lancet Public Health. 2021;S2468-2667(21)001626.

24. California Department of Public Health. Tracking Variants: How has the proportion of variants of concern and variants of interest in California changed over time? Aug 12, 2021. https://www.cdph.ca.gov/Programs/CID/DCDC/Pages/COVID-19/COVID-Variants.aspx.

25. California COVID-19 Dashboard. Cases and Deaths. Aug 12, 2021. https://covid19.ca.gov/state-dashboard/.

26. California Department of Corrections and Rehabilitation. Population COVID-19 Tracking: COVID-19 Trends. Aug 12, 2021. https://www.cdcr.ca.gov/covid19/population-status-tracking/. 
medRxiv preprint doi: https://doi.org/10.1101/2021.08.16.21262149; this version posted August 18, 2021. The copyright holder for this preprint (which was not certified by peer review) is the author/funder, who has granted medRxiv a license to display the preprint in perpetuity.

All rights reserved. No reuse allowed without permission.

\section{ACKNOWLEDGMENTS}

We thank John Dunlap, Heidi Bauer and the other staff members at California Department of Corrections and

Rehabilitation for providing data and assistance with interpretation of study results. We also acknowledge help from members of the Stanford-CIDE Coronavirus Simulation Model (SC-COSMO) consortium.

\section{FUNDING}

Supported in part by the COVID-19 Emergency Response Fund at Stanford, established with a gift from the Horowitz Family Foundation; a grant (R37-DA15612), awarded to Dr. Goldhaber-Fiebert and Dr. Salomon, from the National Institute on Drug Abuse; a grant (NU38OT000297-02), awarded to Dr. Salomon, from the Centers for Disease Control and Prevention through the Council of State and Territorial Epidemiologists; a grant (DGE-

1656518), awarded to Ms. Chin, from the National Science Foundation Graduate Research Fellowship Program; and a grant (OR2020-69521), awarded to Dr. Alarid-Escudero, from Open Society Foundations. 


\section{FIGURES AND TABLES}

Figure 1. Cumulative vaccinations with one or two doses of mRNA vaccines (top panel) and 14-day rolling rates of confirmed infections per 10,000 person-days by vaccination status (bottom panel), among study cohort of incarcerated people in California state prisons. ${ }^{*}$ Shaded areas represent $95 \%$ confidence intervals. Partially vaccinated status defined as $\geq 14$ days after a first dose until receipt of a second dose; fully vaccinated status defined as $\geq 14$ days after a second dose.
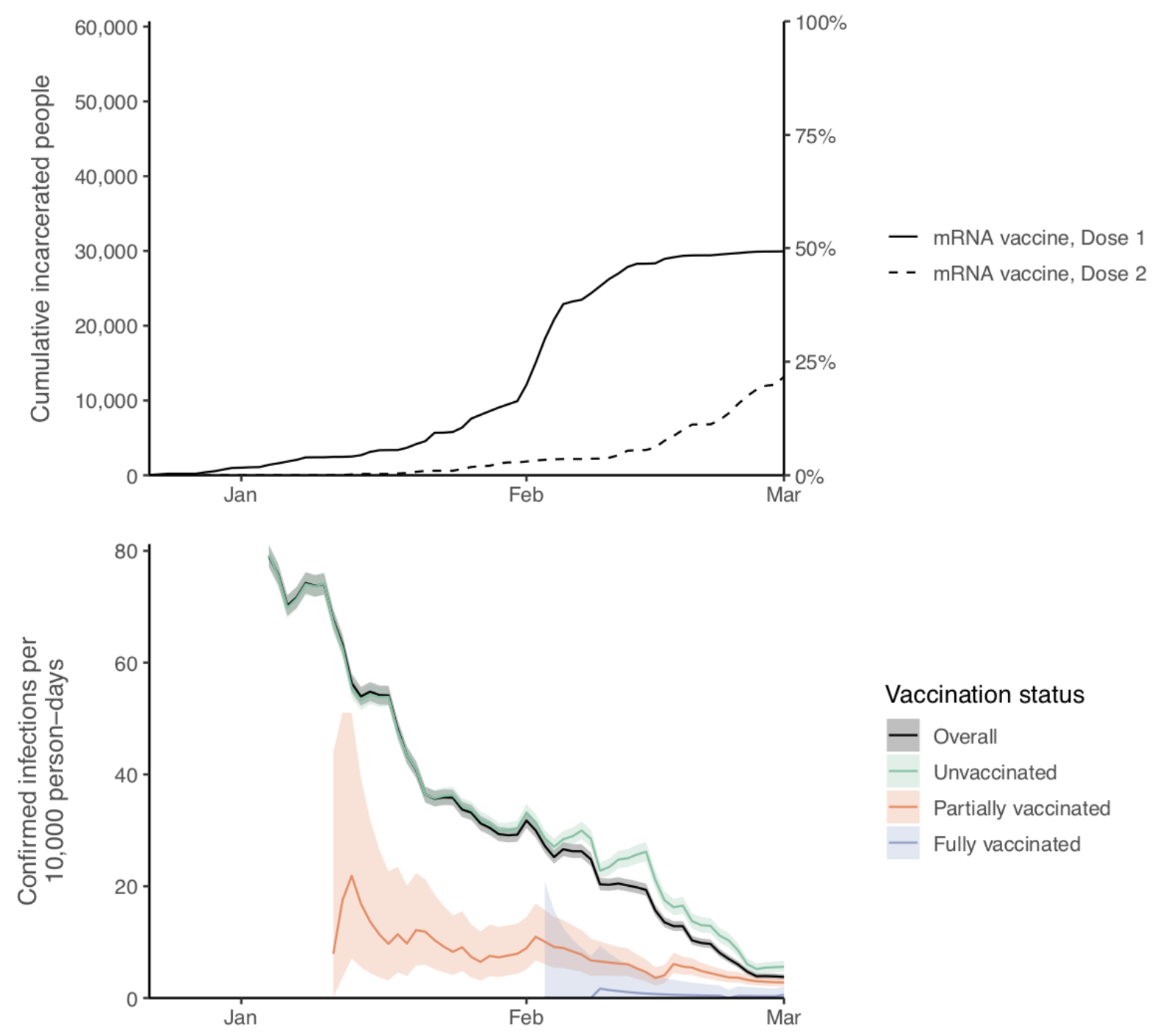

*Time periods with fewer than 200 people tested were excluded. 
medRxiv preprint doi: https://doi.org/10.1101/2021.08.16.21262149; this version posted August 18, 2021. The copyright holder for this preprint (which was not certified by peer review) is the author/funder, who has granted medRxiv a license to display the preprint in perpetuity.

All rights reserved. No reuse allowed without permission.

Table 1. Demographic, health, and carceral characteristics of the study cohort of incarcerated people in California state prisons. Persons within the study cohort were incarcerated on December 22, 2020 and did not have prior confirmed SARS-CoV-2 infection* documented in CDCR clinical records. Vaccinated residents were vaccinated between December 22, 2020 and March 1, 2021.

All Cohort Members

(N=60,707)
Vaccinated Cohort Members ( $\mathrm{N}=\mathbf{2 9 , 9 4 7 )}$

\begin{tabular}{|c|c|c|}
\hline \multicolumn{3}{|l|}{ Demographic characteristics } \\
\hline \multicolumn{3}{|l|}{ Age category } \\
\hline $18-39 y$ & $29,922(49.3 \%)$ & $12,378(41.3 \%)$ \\
\hline $40-59$ y & $23,469(38.7 \%)$ & $12,888(43.0 \%)$ \\
\hline$\geq 60 \mathrm{y}$ & $7,316(12.1 \%)$ & $4,681(15.6 \%)$ \\
\hline \multicolumn{3}{|l|}{ Race or ethnicity ${ }^{\dagger}$} \\
\hline Hispanic or Latino & $25,914(42.7 \%)$ & $13,459(44.9 \%)$ \\
\hline Black or African American & $19,894(32.8 \%)$ & $8,166(27.3 \%)$ \\
\hline White & $10,957(18.0 \%)$ & $6,247(20.9 \%)$ \\
\hline American Indian or Alaska Native & $670(1.1 \%)$ & $325(1.1 \%)$ \\
\hline Asian or Pacific Islander & $833(1.4 \%)$ & $422(1.4 \%)$ \\
\hline Other & $2,439(4.0 \%)$ & $1,328(4.4 \%)$ \\
\hline \multicolumn{3}{|l|}{ Sex } \\
\hline Male & $58,017(95.6 \%)$ & $28,636(95.6 \%)$ \\
\hline Female & $2,661(4.4 \%)$ & $1,311(4.4 \%)$ \\
\hline \multicolumn{3}{|l|}{ Clinical characteristics } \\
\hline \multicolumn{3}{|l|}{ COVID-19 risk score category ${ }^{\star}$} \\
\hline Low $(0-1)$ & $42,093(69.3 \%)$ & $18,829(62.9 \%)$ \\
\hline Moderate (2-3) & $11,509(19.0 \%)$ & $6,415(21.4 \%)$ \\
\hline $\operatorname{High}(\geq 4)$ & $7,105(11.7 \%)$ & $4,703(15.7 \%)$ \\
\hline \multicolumn{3}{|l|}{ Medical conditions } \\
\hline Any pre-existing condition ${ }^{\S}$ & $51,129(84.2 \%)$ & $25,881(86.4 \%)$ \\
\hline Any immunocompromising condition & $2,031(3.3 \%)$ & $1,349(4.5 \%)$ \\
\hline Advanced liver disease & $2,141(3.5 \%)$ & $1,454(4.9 \%)$ \\
\hline Asthma & $8,307(13.7 \%)$ & $4,049(13.5 \%)$ \\
\hline Cancer & $1,773(2.9 \%)$ & $1,159(3.9 \%)$ \\
\hline Chronic kidney disease & $8,889(14.6 \%)$ & $5,406(18.1 \%)$ \\
\hline Chronic obstructive pulmonary disease & $1,757(2.9 \%)$ & $1,207(4.0 \%)$ \\
\hline Connective tissue disorder & $481(0.8 \%)$ & $314(1.0 \%)$ \\
\hline Cardiovascular disease & $3,115(5.1 \%)$ & $1,943(6.5 \%)$ \\
\hline Diabetes & $4,886(8.0 \%)$ & $3,090(10.3 \%)$ \\
\hline HIV & $481(0.8 \%)$ & $309(1.0 \%)$ \\
\hline Hypertension & $15,068(24.8 \%)$ & $8,786(29.3 \%)$ \\
\hline Immunocompromised & $844(1.4 \%)$ & $564(1.9 \%)$ \\
\hline Overweight" & $21,137(34.8 \%)$ & $10,173(34.0 \%)$ \\
\hline Obesity ${ }^{\mathbb{I l}}$ & $21,960(36.2 \%)$ & $11,386(38.0 \%)$ \\
\hline Severe obesity ${ }^{\text {II }}$ & $2,553(4.2 \%)$ & $1,414(4.7 \%)$ \\
\hline \multicolumn{3}{|l|}{ Disability } \\
\hline Any disability ${ }^{\#}$ & $23,422(38.6 \%)$ & $12,892(43.0 \%)$ \\
\hline Cognitive & $993(1.6 \%)$ & $664(2.2 \%)$ \\
\hline Hearing & $2,033(3.3 \%)$ & $1,319(4.4 \%)$ \\
\hline Mental Health & $19,467(32.1 \%)$ & $10,510(35.1 \%)$ \\
\hline Mobility & $6,980(11.5 \%)$ & $4,453(14.9 \%)$ \\
\hline Speech & $96(0.2 \%)$ & $71(0.2 \%)$ \\
\hline Vision & $495(0.8 \%)$ & $323(1.1 \%)$ \\
\hline
\end{tabular}


medRxiv preprint doi: https://doi.org/10.1101/2021.08.16.21262149; this version posted August 18, 2021. The copyright holder for this preprint (which was not certified by peer review) is the author/funder, who has granted medRxiv a license to display the preprint in perpetuity.

All rights reserved. No reuse allowed without permission.

\begin{tabular}{|c|c|c|}
\hline \multicolumn{3}{|l|}{ Carceral characteristics } \\
\hline \multicolumn{3}{|l|}{ Room type } \\
\hline Cell & $45,304(74.6 \%)$ & $22,954(76.6 \%)$ \\
\hline Dorm & $15,403(25.4 \%)$ & $6,993(23.4 \%)$ \\
\hline \multicolumn{3}{|l|}{ Security level } \\
\hline 1 (minimum) & $4,953(8.2 \%)$ & $2,041(6.8 \%)$ \\
\hline 2 & $24,729(40.7 \%)$ & $13,247(44.2 \%)$ \\
\hline 3 & $10,763(17.7 \%)$ & $4,884(16.3 \%)$ \\
\hline 4 (maximum) & $20,262(33.4 \%)$ & $9,775(32.6 \%)$ \\
\hline Participation in penal labor & $15,153(25.0 \%)$ & $7,478(25.0 \%)$ \\
\hline
\end{tabular}

${ }^{*}$ Confirmed by positive PCR or antigen tests.

"All categories other than "Hispanic or Latino" refer to non-Hispanic ethnicity.

"Based on CDCR risk score. See Supplementary Materials Table S1.

${ }^{\S}$ Refers to the set of conditions identified by the Centers for Disease Control and Prevention as risk factors for increased risk of severe COVID-19 illness among adults of any age, specifically: advanced liver disease, asthma, cancer, chronic kidney disease, chronic obstructive pulmonary disease, cardiovascular disease, dementia, Parkinson's, diabetes, on dialysis, hemoglobinopathy disorders, HIV, hypertension, immunocompromised, lung disease, neurologic disorders, pregnancy, vasculitis, overweight, obesity, and severe obesity.

"Refers to diagnosis of immunocompromised, severe HIV, or severe cancer.

"Overweight refers to $25<$ BMI $<30$; obesity refers to $30 \leq$ BMI $<40$; severe obesity refers to $40 \leq$ BMI.

\#Refers to presence of disability in six categories: cognitive, hearing, mental health, mobility, speech, and vision. 
Table 2. Persons, person-days, and vaccine effectiveness against COVID-19 infection among study cohort of incarcerated people in California state prisons, by vaccination status, December 22, 2020 to March 1, 2021.

\begin{tabular}{|c|c|c|c|c|c|c|c|c|c|c|}
\hline COVID-19 vaccination status & $\begin{array}{r}\text { Confirmed } \\
\text { infection* }\end{array}$ & Hospitalized $^{\dagger}$ & Died $^{\ddagger}$ & Tested & Total & $\begin{array}{r}\text { Median } \\
\text { follow-up, } \\
\text { days } \\
\end{array}$ & Person-days & $\begin{array}{r}\text { Positive per } \\
10,000 \\
\text { person-days }\end{array}$ & $\begin{array}{c}\text { Effectiveness, } \\
\text { Unadjusted }^{\S}\end{array}$ & $\begin{array}{r}\text { Effectiveness, } \\
\text { Adjusted }^{\S}\end{array}$ \\
\hline Unvaccinated & 12,318 & 356 & 44 & 53,415 & 60,673 & 43 & $2,633,734$ & 46.8 & (Ref) & (Ref) \\
\hline \multicolumn{11}{|l|}{ Vaccinated with one dose } \\
\hline $0-6$ days after first dose & 527 & 20 & 3 & 19,767 & 29,947 & 7 & 206,960 & 25.5 & $-4 \%(-44$ to 25$)$ & $16 \%(-15$ to 39$)$ \\
\hline 7-13 days after first dose & 237 & 11 & 1 & 17,200 & 28,902 & 7 & 199,746 & 11.9 & $26 \%(-8$ to 50$)$ & $44 \%(20$ to 61$)$ \\
\hline$\geq 14$ days after first dose until second dose & 101 & 4 & 0 & 16,436 & 27,392 & 11 & 286,856 & 3.5 & $63 \%$ (48 to 74$)$ & $74 \%$ (64 to 82$)$ \\
\hline \multicolumn{11}{|l|}{ Vaccinated with two doses } \\
\hline $0-13$ days after second dose & 30 & 2 & 0 & 7,152 & 13,183 & 11 & 120,141 & 2.5 & $74 \%$ (41 to 89 ) & $85 \%$ (66 to 94$)$ \\
\hline$\geq 14$ days after second dose & 3 & 0 & 0 & 2381 & 3,659 & 14 & 50,033 & 0.6 & $93 \%$ (76 to 98$)$ & $97 \%$ (88 to 99$)$ \\
\hline
\end{tabular}

${ }^{*}$ Confirmed SARS-CoV-2 infection is defined as having a positive PCR or antigen diagnostic test for SARS-CoV-2.

Hospitalization related to a SARS-CoV-2 infection is defined as a hospitalization that occurred within three days prior to or 14 days after an infection was initially confirmed. For attribution to person-days stratified by vaccination category, hospitalizations were assigned to the collection date for a confirmed infection.

${ }^{\ddagger}$ All deaths related to a SARS-CoV-2 infection were classified and confirmed by the California Correctional Health Care Services. For attribution to person-days stratified by vaccination category, deaths were assigned to the collection date for a confirmed infection.

${ }^{\S}$ Unadjusted effectiveness estimates based on Cox proportional hazards model with only vaccination status indicators as explanatory variables. Adjusted effectiveness estimates based on Cox proportional hazards model including controls for residents' race or ethnic group (Hispanic, non-Hispanic Black or African American, non-Hispanic White, non-Hispanic American Indian or Alaska Native, non-Hispanic Asian or Pacific Islander, non-Hispanic Other), COVID-19 risk score ( 0 to $\geq 4$, top-coded), security level (1, 2, 3, 4), room type (cell, dorm), involvement in penal labor (yes, no), the prison-specific 7-day rolling COVID-19 case rate for staff (continuous), and prison (fixed-effect). 